\title{
Interlinkage between Governance and Economic Development: A Review of Existing Literature
}

\author{
Smita Lahkar, \\ Research Scholar, Department of Economics, Gauhati University, Assam, India \\ Prof. Nissar Ahmed Barua, \\ Department of Economics, Gauhati University , Assam, India
}

\begin{abstract}
Governance is defined as the exercise of economic, political and administrative authority to manage a country's affairs at all levels. It comprises mechanisms, processes and institutions, through which citizens and groups articulate their interests, exercise their legal rights meet their obligations and mediate their differences. Thus, governance can be summed up as a process through which authority in a country is exercised (UNDP, 1997; UNESCO, 2012). Development linked governance has been an issue much debated about in the contemporary world. Since the second half of the 1980's, growth and development studies have started to shed light on the importance of improving institutions of governance on economic growth. Good institutions, good governance and good leadership are considered by many authors as necessary conditions to support the development effort of a country or region. Good governance is believed to be the single most important factor in eradicating poverty and promoting development, hence, the countries that have a higher rank in the world governance index are often found to be in a higher rank in the other aspects of development.
\end{abstract}

There are several pathways through which governance and its various dimensions can impact a country's economic growth, therefore, in this paper all the key issues related to governance has been discussed which are indispensable for the development of a nation.

Keywords: Governance, institutions, growth, poverty, economic development.

\section{Introduction:}

The term governance can be used specifically to describe changes in the nature and role of the state following the public-sector reforms of the 1980s and 1990s. Typically, these reforms are said to have led to a shift from a hierarchic bureaucracy toward a greater use of markets, quasi-markets, and networks, especially in the delivery of public services. Governance is defined as the exercise of economic, political and administrative authority to manage a country's affairs at all levels. It comprises mechanisms, processes and institutions, through which citizens and groups articulate their interests, exercise their legal rights meet their obligations and mediate their differences. Governance is a process through which authority in a country is exercised (UNDP, 1997; UNESCO, 2012). Governance is "the process of decisionmaking and the process by which decisions are implemented (or not implemented)" (Barua, 2012). Thus, governance can be defined as a process by which public institutions interact with one another as they manage public resources to attain the exalted objective of optimal social welfare.

Development linked governance has been an issue much debated about in the contemporary world. Good institutions, good governance and good leadership are considered by many authors as necessary conditions to support the development effort of a country or region (Talmaciu et al, 2014). 
Development in a nation depends on the social, political and economic conditions prevailing in the country and better political and economic conditions are often guided by the quality of governance existing in that country. The quality of governance plays a vital role in the economic development of a country and without good governance there will be no sustainable development (Kaufmann et al., 2008).Good governance is considered as a key and essential ingredient of social and economic development, especially in developing countries. The research work conducted by the international organizations such as International Monetary Fund (IMF), the United Nations and the World Bank shows that good governance leads to economic growth. Policy makers and academics agree that good governance is essential for economic development and it is believed to be the single most important factor in eradicating poverty and promoting development. It has been discovered that highquality institutions have the power, over the long run, to raise per capita income and promote growth in all parts of the world and the "development dividend" due to good governance is also huge (World Bank Report, 2006). In fact, the ability to measure and monitor the progress on key dimensions of governance such as rule of law, corruption and voice and accountability has enabled reformers in government and civil society to press for improvements in the quality of governance in many countries.

This paper makes an attempt to study the existing literature available on governance and the various issues related to governance are studied in the following sections. There are several pathways through which governance and its various dimensions can impact a country's economic growth, therefore, in this paper all the key issues related to governance has been discussed which are indispensable for the development of a nation.

\section{Good Governance and its Principles:}

The Worldwide Governance Indicators is a programme funded by the World Bank that measures the quality of governance in more than 200 countries. The six indicators of good governance according to World Bank are: Voice and Accountability, Political Stability, Lack of violence, Government Effectiveness, Regulatory Quality, Rule of Law and Control of Corruption. Similarly, UNDP has also pointed out 8 major characteristics of good governance: Participation, Rule of Law, Transparency, Responsiveness, Consensus Orientation, Equity, Effectiveness and efficiency, Accountability and Strategic Vision. Thus, governance to be effective, must have the characteristic of an efficient public service, an independent judicial system and legal framework to enforce contracts; the accountable administration of public funds; an independent public auditor, responsible to a representative legislature; respect for the law and human rights at all levels of government; a pluralistic institutional structure, and a free press (World Bank, 2004). Hence, good governance is, among other things, participatory, transparent and accountable and promotes the rule of law along with being effective and equitable.

\section{Governance Measurement:}

The concept of governance varies in its definition and has been gauged by many economists by its individual aspects. Measuring the multiple dimensions of governance is necessary to provide a quantifiable tool to monitor governance performance and progress and support the development of effective and responsive policy solutions. Many economists feel that there is a pressing need to study the variety of indicators while assessing governance. The World Bank has used aggregate indicators to capture the essence of governance as these are based on widely accepted criteria and improves reliability. Aggregate indicators yield more reliable information about governance than any individual indicator can provide (World Bank Report, 2006). However, there is a debate regarding the usefulness of aggregate indicators as it is believed that there is a 
loss in the amount of information due to the simplification made by the index. Even then this is the most widely used practice of measuring governance. Some of the most extensively used indexes of governance are World Governance Index (WGI), Corruption Perception Index (CPI), Ibrahim Index of African Governance (IIAG), Indonesia Governance Index (IGI).

\section{Governance and Economic Development:}

Since the second half of the 1980's, growth and development studies have started to shed light on the importance of improving institutions of governance on economic growth (Emara and Chiu, 2016). Good institutions or more specifically good governance is considered as necessary condition to support the development effort of a country. The implementation of the principles of good governance has helped many countries to come out of the grasps of poverty, unemployment and inequality. The advocates of the development phenomenon have shifted their focus from the analysis of effects of some the traditional variables such as accumulation of physical and human capital, technical and technological progress to the study of implications of some qualitative variables characteristic to the sociologic studies such as institutions, governance quality, aspects of the cultural context and social capital (Talmaciu et al, 2014). The differences in economic performance among nations can be attributed to the difference in institutions (Acemogolu,et. al. 2000). Countries that have sound institutional policies have better growth rates compared to those which have minimum institutional set ups. This notion has been proved by studies that have done econometric analysis and have found positive relation between economic development and better governance conditions. Emara and Chiu (2016) have conducted their studies in the MENA (Middle Eastern and North African) region in which out of the nine countries of the MENA region have shown a positive correlation between governance and economic growth which includes those countries that have experience deterioration accompanied by deterioration and those countries that have experienced an enhancement accompanied by an enhancement in governance index and in economic growth, respectively. The better institutional mechanism could actually help economies to grow faster with higher level of economic well-being (Basu, 2004).Thus, governance has emerged as a key candidate for the paradigm for development and the issue of good governance is widely regarded as one of the key ingredient for poverty alleviation and sustainable development.

\section{Governance and Per Capita Income:}

There runs a positive link from provisioning of better institutional mechanism to rising per capita income growth and higher level of well-being (Basu, 2004; Rodrik et al. 2004). An improvement in governance of one standard deviation can triple a nation's per capita income in the long run (World Bank Report, 2006). The 'development dividend' of good governance is believed to go up to 300 percent. A country that has today $\$ 2,000$ per capita income per year can attain $\$ 6,000$ per capita income per year in the long term if it improves its rule of law, control corruption and government effectiveness." Emara and Chiu (2016) have found in their study that the per capita GDP would rise by about $2 \%$ if the CGI increases by one unit.

Rodrik (2003) argues that it is possible to achieve growth up to middle income level despite some corruption, but cleaner and better institutions are needed to go beyond that to a higher-income level. In context of India, the economically more advanced part of it is just on the cusp of this transition to and beyond the middle-income level, and therefore people are beginning to see the need for much better institutions in order to attain higher per capita income.

\section{Governance and Human Development:}

Governance is the process and institutions through which decisions are made and authority in a country is exercised and it rests on the twin pillars 
of inclusiveness and accountability (World Bank Institute).Investors will drive away from a politically unstable, bureaucratic, and highly corrupted economies with inefficient and nontransparent government services. A government that is socially accountable in delivering services and responsive to the needs of its citizens will ultimately create a democratic environment leading to inclusive growth and human development (Emara and Chiu, 2016).

Dimension of good governance like accountability, participation and corruption control have a direct relation to the human development. Higher the levels of these dimensions represent higher levels of human development but other factors like government inefficiency and effectiveness, bribery if not controlled and regulated can reduce the Human Development.

\section{Governance and Government:}

The term 'governance' is distinguished from government, which is a formal body invested with the authority to make decisions in a given political system. Governance is the process while government is the structure. The idea of governance is often erroneously perceived to be government activity. Governance is not synonymous with government and the failure to distinguish between them can result in serious flaw (Barua, 2012, Graham et. al. 2003). Governance and government are two different terms and requires being distinguished. Government refers to any formal body in a political system which has the authority to take decisions whereas governance is the whole process which influences the decision making process In the case of a government, the governance process includes the functions of all the actors involved in influencing the decisionmaking process, such as all citizens, political parties, media, the electoral process, elected leaders, form of government and is mainly concerned with the processes of the elected government and the bureaucracy that function together to implement the laws and regulations. It is a process by which the governments realize the goals set for themselves, effectively and efficiently within the time specified Governance may be defined as a government's ability to make and enforce rules, and to deliver services (Fukuyama, 2013). Thus, good governance refers to the task of running the Government in an effective manner.

\section{Governance and Decentralization:}

Successful decentralization is not just about building good political institutions, it is also essential to improve overall governance at the local level. Decentralized governance was expected to promote development when it presents necessary conditions like peoples' participation, accountability, transparency and capacity building.

Decentralization means tackled more easily in a national context, or in the context of federal nations (USA, Germany, Canada), which have an higher degree of decentralization of authorities and various levels of government, making it difficult to address in the context of countries with a high level of centralization.

Decentralization and quality of governance can be related by using four aspects which are participation, government orientation, social development and macroeconomic management. It was seen that the government aiming at the reforming the administrative system put more emphasis on decentralizing authority to the lower tiers of government. Delegation of authority to the lower levels of government leads to better coordination and management of the policies and programmes implemented. Thus, resources suggest that decentralized governance may be better for long term growththrough greater conservation of local resources.

\section{Governance and Corruption:}

Corruption is defined as exercise of official powers against public interest or the abuse of public office for private gains (Shah, 2006). It is 
very strongly believed that corruption and good governance are very closely linked and there lies a positive correlation between corruption and economic growth. The corruption perception index, that ranks countries based on the country's perceived level of public sector corruption, found a correlation between a higher CPI and higher long-term economic growth, as well as an increase in GDP growth of $1.7 \%$ for every unit increase in a country's CPI score.

The economic consequences of corruption is that it affects the education sector, the infrastructural sector, health services and is also believed to bring down the per capita income which adversely affects the GDP growth rate. Increase in corruption has detrimental impact on development (World Bank, 2004). It diverts funds intended for development, undermines the ability of governments to provide basic services, feeds inequalities and injustice, and discourages foreign aid investment.

Often governance deficit arises due to high levels of corruption in the delivery of public services in low income economies. Corruption in the delivery of public programs, in form of leakages, theft and graft, can have significant implications for growth. Establishing a causal relationship between corruption and growth in a macroeconomic framework is challenging due to the endogenous nature of corruption. Hence,corruption can be attributed to the failure of governance. Poor governance and corruption have made it more difficult for the poor and other disadvantaged groups to obtain public services.

\section{Governance and Security Discourse:}

The foremost principle of world governance is to build an environment that is safe and secure. The concept of security as defined by the world governance report can be explained under two categories - national security and public security. The quality of governance and institutions influences the level of trust among citizens (Talmaciu et al., 2014).
There is a crucial link between "National Governance" and "Internal Security" and governance cannot be delivered if internal security is not maintained and there would be grave threats to the unity and integrity of the country (Vohra, 2008). The effective enforcement of the 'Rule of law' principle of governance is crucial for the safeguarding of national security and delivery of good governance.

Social unrest is bound to grow unless the issues of poverty, nutrition and education are addressed properly and these also adversely affect the development of a nation. Poverty, human rights abuse, denial of justice and absence of inclusive policies lead to the sharpening of the social and political divide (Upadhaya, 2016). These challenges can be attributed to a number of factors such as ethnic differences, structural weakness, deregulation and structural adjustments, however, governance failure can be identified as the most prominent one which overshadows all the other factors. Hence, a nation must address these issues so that development can take place.

\section{Conclusion:}

Governance is a multi faceted concept and the concept of governance has been defined differently by different institutions and scholars and is used in a number of different fields. Governance being a multi-disciplinary subject, a numerous studies has been done on government and its governance related issues. The main focuses of these studies have been on the principles of representation, responsiveness and accountability of the elected representatives. In the rapidly changing world, good governance has become one of the important concepts to emphasize on and due to the consciousness of the modern public; the governments are trying to make their systems accountable and transparent. India has managed to sustain a reasonably vibrant democracy and civil society. While bureaucratic aspects of democratic governance have been largely sustained, the substantive aspects remain elusive. As such, public institutions are 
inaccessible to large numbers of people especially to the poor and the illiterate. Even thoughthe capability of the institutional set up of the country is unquestionable; India's structures of governance seem to have remained inadequate in many aspects. Good governance, more than policies and reforms, is the key for India to achieve inclusive growth. While the economic reforms have taken the country to the fore, restoring accountability in governance will answer many development issues that will make the country one of the leading economies in the world.

\section{References:}

1. Acemoglu, D., S. Johnson and J. A. Robinson (2000), "The Colonial Origins of Comparative Development", American Economic Review, 91(5): 1369-1401.

2. Barua, N. A. (2012) "Governance and Economic Development", International Journal of Innovative Research and Development, 1(9):192200.

3. Basu, S.R. (2004) "Economic Growth, WellBeing and Governance under Economic Reforms: Evidence from Indian States", HEI Working Paper No: 05/2004, Graduate Institute of International Studies, Geneva.

4. Emara, N. and I. M. Chiu (2016) "The Impact of Governance on Economic Growth: The Case of Middle-Eastern and North African Countries", Topics in Middle Eastern and African Countries, 18(1): 126-144.

5. Fukayama, F. (2013) "What is Governance?", Governance: An International Journal of Policy, Administration and Institution, 69(3): 347- 368.

6. Kaufmann, D., A. Kraay and M. Mastruzzi (2008) "Governance Matters VIII: Aggregate and Individual Governance Indicators 1996-2008", Policy Research Working Paper 4978, World Bank.

7. Shah, A. (2006) "Corruption and Decentralised Public Governance", World Bank Woking Paper Series, 3284.

8. Talmaciu, M. and A. I. Cuza (2014) "Study on the Relationships between Institutions,
Governance and Leadership and Regional Development Policy in Romania".

[Online]

Available: www.sciencedirect.com

[accessed on $13^{\text {th }}$ February,2018]

9. UNDP (2014) Governance for Sustainable Development. New York.

10. World Bank Report (2006) A Decade of Measuring the Quality of Governance, Governance Matters, 2006 .Washington: World Bank. 